\title{
STUDI PEMANFAATAN LIMBAH TANDAN KOSONG KELAPA SAWIT OLEH MASYARAKAT DI JORONG KOTO SAWAH NAGARI UJUNG GADING KECAMATAN LEMBAH MELINTANG
}

\author{
Salmina \\ Program Studi Pendidikan Geografi STKIP PGRI Sumatera Barat \\ Salmina92@gmail.com
}

\begin{abstract}
This study aims to know waste utilization of oil palm empty fruit bunches in Jorong Koto Sawah Nagari Ujunggading District Of Lembah Melintang West Pasaman. This type of research is descriptive. The population is head of the family in Jorong Koto Sawah Nagari Ujunggading District of Lembah Melintang totaled 1141 households. Samples were taken by purposive sampling region (designation) with 3 Jorong Koto Sawah 1) Dusun Banjar Kapar, 2) Dusun Muara Simpang, 3) Dusun Tanjung Harapan which has the highest number of people in Jorong Koto Sawah. The sample of respondents was taken with the proportion of $25 \%$ of the number of households, so that a population of 100 families. Data collection through questionnaires or instruments. Techniques of analysis using the analysis of the percentage formula. The research found that: (1) Awareness of the utilization of waste palm empty fruit bunches are in less good criteria, with a percentage of 56,8\%, (2) Public Participation on the utilization of waste oil palm empty fruit bunches are in less good criteria, with a percentage of 56,9\%, and (3) Motivation Communities to the utilization of waste oil palm empty fruit bunches are in the criteria is not good, with a percentage of $53.5 \%$
\end{abstract}

\section{PENDAHULUAN}

Perkembangan ekonomi di era globalisasi menyebabkan pertambahan konsumsi energi di berbagai sektor kehidupan. Bukan hanya negara-negara maju, tapi hampir semua negara termasuk Indonesia mengalaminya. Ancaman menipisnya cadangan minyak dunia, mendorong pemerintah untuk mengeluarkan Peraturan Presiden (Perpres) No. 5 Tahun 2006 Tanggal 25 Januari tentang kebijakan energi nasional dan Instruksi Presiden (Inpres) No 1 Tahun 2006 tentang penyediaan dan pemanfaatan bahan bakar nabati (BBN) sebagai bahan bakar lain.

Undang Undang (UU) Republik Indonesia Nomor 18 Tahun 2008 Tentang Pengolahan Sampah,menjelaskan bahwa kondisi pengolahan sampah di Indonesia umumnya belum sesuai dengan metode pengolahan sampah yang berwawasan lingkungan sehingga menimbulkan dampak negatif terhadap kesehatan masyarakat dan lingkungan.

TKKS (Tandan Kosong Kelapa Sawit) di Indonesia adalah limbah pabrik kelapa sawit yang jumlahnya sangat melimpah. Setiap pengolahan 1 ton TBS (Tandan Buah Segar) akan dihasilkan TKKS (Tandan Kosong Kelapa Sawit) sebanyak 22-23\% TKKS (Tandan Kosong Kelapa Sawit) atau sebanyak 220-230 
kg TKKS. Limbah ini belum dimanfaatkan secara baik oleh sebagian besar pabrik kelapa sawit (PKS) dan masyarakat di Indonesia. Pengolahan/pemanfaatan TKKS oleh PKS masih sangat terbatas. Sebagian besar pabrik kelapa sawit (PKS) di Indonesia masih membakar TKKS dalam incinerator, meskipun cara ini sudah dilarang oleh pemerintah. Alternatif pengolahan lainnya adalah dengan menimbun (open dumping), dijadikan mulsa di perkebunan kelapa sawit, atau diolah menjadi kompos.

Tandan kosong kelapa sawit merupakan limbah terbesar yang dihasilkan oleh perkebunan kelapa sawit. Jumlah tandan kosong mencapai 30-35 \% dari berat tandan buah segar setiap pemanenan. Namun hingga saat ini, pemanfaatan limbah tandan kosong kelapa sawit belum digunakan secara optimal (Hambali, dkk. 2007).

Di Jorong Koto Sawah masyarakat memiliki akses yang cukup dekat dengan paprik PT. BNC Pasaman Plantation sehingga masyarakat bisa dengan mudah dapat memanfaatkan limbah tandan kosong kelapa sawit, tapi pada kenyataanya masyarakat Koto Sawah tidak menyadari akan pentingnya pemanfaatan limbah tandan kosong kelapa sawit. Limbah tandan kosong kelapa sawit sangat baik untuk lahan pertanian warga baik itu untuk perkebunan kelapa sawit, jeruk dan berbagai macam tanaman lain. (Kepala Jorong Koto sawah, 2015)

TKKS (Tandan Kosong Kelapa Sawit) digunakan sebagai bahan organik bagi pertanaman kelapa sawit secara langsung maupun tidak langsung. Pemanfaatan secara langsung ialah dengan menjadikan TKKS (Tandan Kosong Kelapa Sawit) sebagai material penutup budidaya untuk menjaga kelembaban tanah (mulsa) sedangkan secara tidak langsung dengan mengomposkan terlebih dahulu sebelum digunakan sebagai pupuk organik. Bagaimanapun juga, pengembalian bahan organik kelapa sawit ke tanah akan menjaga pelestarian kandungan bahan organik lahan kelapa sawit demikian pula hara tanah. Selain itu, pengembalian bahan organik ke tanah akan mempengaruhi populasi mikroba tanah yang secara langsung dan tidak langsung akan mempengaruhi kesehatan dan kualitas tanah. Aktivitas mikroba akan berperan dalam menjaga stabilitas dan produktivitas ekosistem alami, demikian pula ekosistem pertanian. (Barea et al. 2005). 
Komponen utama limbah pada kelapa sawit ialah selulosa dan lignin, sehingga limbah ini disebut sebagai limbah lignoselulosa (komponen utama tumbuhan) (Darnoko, 1993). Selulosa adalah senyawa karbon yang terdiri lebih dari 1000 unit glukosa yang terikat oleh ikatan beta 1,4 glikosida dan dapat didekomposisi oleh berbagai organisme selulolitik menjadi senyawa $\mathrm{C}$ sederhana. Sedangkan lignin merupakan komponen limbah TKKS (tandan kosong kelapa sawit) yang relatif sulit didegradasi. Senyawa ini merupakan polimer struktural yang berasosiasi dengan selulosa dan hemiselulosa. Jamur Pelapuk Putih (JPP) merupakan kelompok jamur yang dikenal menghasilkan enzim ligninolitik secara ekstra seluler sehingga mampu mendegradasi lignin untuk mendapatkan hara yang diperlukan untuk pertumbuhannya. Salah satu JPP yang dapat dikonsumsi adalah jamur merang (Volvariella volvacea). Jamur merang bersifat saprofitik sehingga memerlukan sumber karbon untuk pertumbuhannya. Untuk mencukupi kebutuhan karbon, jamur merang melakukan dekomposisi bahan organik menghasilkan senyawa karbon sederhana di samping hara yang tersedia yang digunakan untuk pertumbuhannya. (Basuki, 1991)

Lingkungan masyarakat masalah tersebut di atas merupakan hal yang biasa dan tidak cukup menarik untuk dipermasalahkan. Akan tetapi kalau dibiarkan begitu saja justru dapat menimbulkan pengaruh yang kurang baik, terutama terhadap kebersihan lingkungan dan kesehatan. Pada prinsipnya kesehatan masyarakat memerlukan adanya keikutsertaan masyarakat dalam menjaga kebersihan lingkungan terutama penanam budaya hidup bersih dan sehat dalam keluarga sejak dini. (Basuki, 1991)

Pemanfaatan limbah memerlukan upaya-upaya yang dapat merubah persepsi masyarakat yang dahulu beranggapan bahwa limbah itu dapat digunakan dan bisa menghasilkan nilai ekonomi. Dari perubahan persepsi tersebut akan menimbulkan pengaruh posiitif pada masyarakat terhadap kegiatan pengolahan limbah tandan kosong kelapa sawit, dengan persepsi yang benar, diharapkan akan menumbuhkan motivasi masyarakat untuk ikut berpartisifasi dalam kegiatan pemanfaatan limbah tandan kosong kelapa sawit. Sikap positif yang mempertimbangkan etika lingkungan, akan mendorong partisifasi akatif masyarakat dalam kegiatan pemanfaatan limbah tandan kosong kelapa sawit. (Basuki, 1991) 
Tandan kosong kelapa sawit mempunyai potensi yang besar untuk digunakan sebagai bahan penyubur tanah karena sifat kimia dan fisik yang dapat memperbaikai kondisi tanah (Anomius : 2003). Jika dibandingkan dengan bahan penyubur tanah lainnya. Tandan kosong kelapa sawit merupakan salah satu pupuk organik yang mengandung kalium $(\mathrm{K})$ cukup tinggi selain kandungan nitrogen $(\mathrm{N})$ dan fosfor $(\mathrm{P})$.

\section{METODOLOGI}

Sesuai dengan pembatasan dan perumusan masalah maka jenis penelitian ini tergolong pada penelitian deskriptif, yaitu penelitian yang bertujuan untuk melihat, menyikapi, menggambarkan dan mendeskripsikan bagaimana Pemanfaatan Limbah Tandan Kosong Kelapa Sawit oleh Masyarakat di Jorong Koto Sawah Nagari Ujunggading Kecamatan Lembah Melintang Kabupaten Pasaman Barat.

Menurut Iskandar (2009) penelitian deskriptif adalah penelitian yang memberikan uraian mengenai fenomena atau gejala sosial yang diteliti.

\section{Informan Penelitian}

Sampel wilayah diambil dengan purposive sampling (penunjukan) dengan mengambil tiga (3) Dusun di Jorong Koto Sawah. 1) Banjar Kapar, 2) Muara Simpang, 3) Tanjung Harapan. Adapun alasan penetapan sampel wilayah adalah karena ketiga wilayah di atas tersebut merupakan wilayah yang mempunyai jumlah KK paling banyak di Jorong Koto Sawah Nagari Ujunggading

\section{Teknik Pengambilan Informan}

Sampel wilayah diambil dengan purposive sampling (penunjukan) dengan mengambil tiga (3) Dusun di Jorong Koto Sawah. 1) Banjar Kapar, 2) Muara Simpang, 3) Tanjung Harapan. Adapun alasan penetapan sampel wilayah adalah karena ketiga wilayah di atas tersebut merupakan wilayah yang mempunyai jumlah KK paling banyak di Jorong Koto Sawah Nagari Ujunggading.

\section{Teknik dan Alat Pengumpulan Data}

Teknik penggumpulan data yang dapat dilakukan dalam penelitian ini adalah sebagai berikut:

1. Jenis data 
Sesuai dengan tujuan penelitian, maka data yang dicari dan dikumpulkan adalah berupa data primer. Data primer berupa kesadaran, partispasi dan motivasi pemanfaatan limbah tandan kosong kelapa sawit di Jorong Koto Sawah Nagari Ujunggading Kecamatan Lembah Melintang. Sedangkan data sekunder berupa gambaran umum daerah penelitian, kondisi sosial dan lain sebagainya.

2. Sumber data

Sesuai dengan jenis data yang diambil dalam penelitian ini maka sumber data primernya adalah responden yaitu masyarakat. Sedangkan data sekundernya diperoleh dari kantor Kepala Jorong dan Wali Nagari.

3. Alat pengumpulan data

Data primer dikumpulkan melalui wawancara dengan daftar pertanyaan (kuesioner) yang telah disiapkan sebelumnya. Data sekunder diperoleh melalui observasi serta pencatatan data sesuai dengan yang diburuhkan untuk penelitian.

\section{Teknik Analisis Data}

Sesuai dengan tujuan dan penelitian, teknik analisis data yang digunakan dalam penelitian ini adalah analisis Deskriptif dengan menggunakan rumus formula persentase. Adapun analisis statistik yang digunakan dalam penelitian ini adalah :

Rumus persentase :

$$
P=\frac{\text { frekuensi }(f)}{\text { jumlah responden }(n)} \times 100 \%
$$

\section{PEMBAHASAN}

Pada pembahasan ini akan dibahas hasil penelitian tentang studi pemanfaatan limbah tandan kosong kelapa sawit di Jorong Koto Sawah Nagari Ujunggading Kecamatan Lembah Melintang Kabupaten Pasaman Barat yang meliputi: 1) Kesadaran masyarakat terhadap pemanfaatan limbah tandan kosong kelapa sawit, 2) Partisipasi masyarakat dalam pemanfaatan limbah tandan kosong kelapa sawit dan, 3) Motivasi masyarakat terhadap pemanfaatan limbah tandan kosong kelapa sawit.

Pertama, kesadaran masyarakat terhadap arti pemanfaatan limbah tandan kosong kelapa sawit dan kesediaan masyarakat terhadap pemanfaatan limbah tandan kosong kelapa sawit masih sangat rendah. Kesadaran masyarakat skor rata- 
ratanya adalah 2,84 dengan tingkat capaian responden 56,8 yang berada pada kriteria kurang baik.

Salim (1989) menyatakan bahwa kesadaran merupakan usaha untuk memulihkan kemampuan insan itu sendiri yang harus menjadi titik tolak dan menjadi kehendak untuk melakukan perbaikan-perbaikan. Selanjutnya Ahmad (1987) dalam Cardinal (1995) menengemukakan pengertian kesadaran adalah kesediaan dari masyarakat untuk mengambil keputusan dalam menghadapi belajar konflik.

Penyebab kesadaran masyarakat kurang baik karena lemahnya kesadaran masyarakat terhadap tujuan pemanfaatan limbah tandan kosong kelapa sawit dan penggunaan limbah tandan kosong kelapa sawit sebagai pupuk alternative perngganti pupuk kimia serta masih rendahnya kepedulian masyarakat terhadap lingkungan.

Hal ini berarti kesadaran adalah kesediaan dari masyarakat untuk mengambil keputusan, namun pada hasil penelitian kesadaran masyarakat terhadap pemanfaatan limbah tandan kosong kelapa sawit di Jorong Koto Sawah masih kurang baik dan perlu untuk ditingkatkan.

Kedua, partisipasi masyarakat skor rata-ratanya 2,85 dengan tingkat capaian responden $56,9 \%$ yang berada pada kriteria kurang baik. Hal ini terlihat bahwa pemanfaatkan limbah tandan kosong kelapa sawit sebagai pupuk alternative, kompos belum baik, serta kesediaan masyarakat dalam pemanfaatan limbah tandan kosong masih kurang.

Thoha (2007) mengatakan bahwa dasar pokok yang amat penting atas partisipasi seseorang dalam kehidupan berkelompok adalah kesempatannya untuk berintegrasi dengan pihak lain. Bila seseorang jarang melihat atau berbicara dengan pihak lain, akan sulit dapat tertarik. Oleh karena itu, partisipasi seseorang dalam berorganisasi atau kelompok, ditentukan oleh adanya daya tarik.

Hal ini berdasarkan teori berarti masyarakat Jorong Koto Sawah belum terlalu tertarik untuk pemanfaatan limbah tandan kosong kelapa sawit, namun masyarakat memiliki partisipasi walaupun masih kurang baik, sehingga perlu adanya upaya untuk meningkatkan partisipasi masyarakat dengan cara membuat program yang langsung dengan kepentingan masyarakat serta keikutsertaan 
pemerintah setempat disertai masyarakat dalam program pemanfaatan limbah tandan kosong kelapa sawit.

Ketiga, motivasi masyarakat skor rata-ratanya adalah 2,68 dengan tingkat capaian responden 53,5\% yang berada pada kriteria tidak baik. Motivasi dilihat dari keinginan masyarakat untuk memanfaatkan limbah tandan kosong kelapa sawit. Hal ini memperlihatkan bahwa di Jorong Koto Sawah masyarakat masih tidak termotivasi terhadap pemanfaatan limbah tandan kosong kelapa sawit yang disebabkan masih kurangnya perhatian dari pemerintah setempat dan kurangnya penyuluhan dari pemuka masyarakat.

Slamet (2009:195) Motivasi dapat diartikan sebagai kekuatan (energi) seseorang yang dapat menimbulkan tingkat persistensi dan antusiasmenya dalam melaksanakan sesuatu kegiatan, baik yang bersumber dari dalam diri individu itu sendiri (motivasi instrisik) ataupun dari luar individu (motivasi ekstrinsik). Seberapa kuat motivasi yang dimiliki individu akan banyak menentukan terhadap kualitas perilaku yang ditampilkannya, baik dalam konteks belajar, bekerja maupun dalam kehidupan lainnya.

Hal ini terlihat berdasarkan teori berarti motivasi masyarakat dalam pemanfaatan limbah tandan kosong kelapa sawit timbul karena adanya keinginan masyarakat tersebut. Disamping itu peranan pemimpin masyarakat juga akan menumbuhkan motivasi masyarakat dalam pemanfaatan limbah tandan kosong kelapa sawit.

\section{KESIMPULAN}

Dari hasil penelitian terhadap pemanfaatan limbah tandan kosong kelapa sawit di Jorong Koto Sawah dapat disimpulkan sebagai berikut:

1. Kesadaran masyarakat dalam pemanfaatan limbah tandan kosong kelapa sawit masih kurang baik dan masih perlu untuk ditingkatkan. Skor rataratanya adalah 2,84 dengan tingkat capaian reponden 56,8 yang berada pada kriteria kurang baik.

2. Partisipasi masyarakat terhadap pemanfaatan limbah tandan kosong kelapa sawit masih kurang baik. Skor rata-ratanya 2,85 dengan tingkat capaian responden 56,9\% yang berada pada kriteria kurang baik. Hal ini berarti masyarakat di Jorong Koto Sawah memiliki partisipasi walaupun masih kurang baik, sehingga perlu adanya upaya untuk meningkatkan partisipasi 
masyarakat dengan cara membuat program yang langsung dengan kepentingan masyarakat serta keikutsertaan pemerintah setempat disertai masyarakat dalam program pemanfaatan limbah tandan kosong kelapa sawit.

3. Motivasi masyarakat terhadap pemanfaatan limbah tandan kosong kelapa sawit tidak baik dan perlu untuk ditingkatkan. Skor rata-ratanya adalah 2,68 dengan tingkat capaian responden 53,5\% yang berada pada kriteria tidak baik. Hal ini terlihat bahwa motivasi masyarakat dalam pemanfaatan limbah tandan kosong kelapa sawit timbul karena adanya keinginan masyarakat tersebut. Disamping itu peranan pemimpin masyarakat juga akan menumbuhkan motivasi masyarakat dalam pemanfaatan limbah tandan kosong kelapa sawit.

\section{DAFTAR PUSTAKA}

Dwiningrum, Siti Irene Astusi. 2011. Desentralisasi dan Partisipasi Masyarakat dalam Pendidikan. Yoyakarta : Pustaka Pelajar

Sutedjo, Mul. Mulyani dan Kartasapoetra. 1987. Pengantar Ilmu Tanah. Jakarta : PT. Bina Aksara

Thoha. Miftah. 2007. Perilaku Organisasi, Konsep Dasar dan Aplikasinya. Jakarta: Raja Grafindo

Veronica. A.Kumurur. 2007. Pendidikan dan Kesadaran. http://wikipedia.org. Akses Tanggal 27 April 2015

Hardjowinego, Sarwono. 1987. Ilmu Tanah. Jakarta : CV. Akademika Pressindo

Harmanto, Gatot. 2013. Geografi Berbasis Pendidikan Karakter Bangsa. Bandung : Yrama Widya 